\title{
Skenario Pengembangan Sistem Pengelolaan Sampah Kabupaten Pasaman Barat dengan Pendekatan Skala Pengolahan Sampah di Tingkat Kawasan dan Kota
}

\author{
Rizki Aziz ${ }^{1 *}$, Taufiq Ihsan², Ade Septia Permadani ${ }^{3}$ \\ 1,2,3 Jurusan Teknik Lingkungan, Fakultas Teknik, Universitas Andalas, \\ Kampus Limau Manis, Padang, 25163, Indonesia \\ *Koresponden email: rizkiaziz@ft.unand.ac.id
}

Diterima : 19 Maret 2019

Disetujui: 26 Maret 2019

\begin{abstract}
This study aims to analyze the existing conditions of the solid waste management system in Pasaman Barat Regency and discuss the alternative development of solid waste management systems with a solid waste treatment approach at the regional and municipal scale as a solution to the problem of solid waste management in Pasaman Barat Regency. From this study it is known that the level of existing solid waste management services was only $9.13 \%$ of total solid waste generated. The problems faced in solid waste management in Pasaman Barat Regency were still high levels of unserved solid waste, inadequate operational facilities and infrastructure for solid waste management, uneven handling of solid waste in service area coverage and the low practice of waste minimization and utilization. The solid waste man-agement system in Pasaman West Regency in the future can apply a combination of solid waste manage-ment approaches at the regional level based on Solid Waste Treatment Station with reduce-reuse-recycle approach (TPS 3R) in domestic areas and treatment at the city level based on Intergrated Solid Waste Treatment Station (TPST) at the landfill site, with the development of the system planned for 15 years, solid waste volume taken into the landfill site can be reduced by $22.40 \%$.
\end{abstract}

Keywords: solid waste management system, Pasaman Barat, regional scale, city scale

\begin{abstract}
Abstrak
Studi ini bertujuan untuk menganalisis kondisi eksisting sistem pengelolaan sampah di Kabupaten Pasaman Barat dan mengkaji alternatif pengembangan sistem pengelolaan sampah dengan pendekatan pengolahan sampah di skala kawasan dan kota sebagai solusi terhadap permasalah sampah di Kabu-paten Pasaman Barat. Dari studi ini diketahui bahwa tingkat pelayanan pengelolaan sampah eksisting hanya 9,13\% dari total sampah. Permasalahan yang dihadapi dalam pengelolaan sampah Kabupaten Pasaman Barat adalah masih tingginya timbulan sampah yang tidak terlayani, sarana dan prasarana teknis operasional sampah yang kurang memadai, belum meratanya penanganan sampah pada cakupan daerah layanan dan rendahnya praktik minimasi dan pemanfaatan sampah. Sistem pengelolaan sampah di Kabupaten Pasaman Barat kedepannya dapat menerapkan kombinasi antara pendekatan pengolahan sampah di tingkat kawasan yang berbasis pada Tempat Pengolahan Sampah berbasis Reduce-Reuse-Recycle (TPS 3R) di kawasan pemukiman dan pengolahan di tingkat kota yang berbasis pada Tempat Pengolahan Sam-pah Terpadu (TPST) di lokasi Tempat Pemrosesan Akhir (TPA) sampah, dengan pengembangan sistem ini direncanakan dalam 15 tahun volume sampah yang dibawa ke TPA dapat berkurang sebanyak 22,40\%.
\end{abstract}

Kata kunci: sistem pengelolaan sampah; Pasaman Barat; skala kawasan; skala kota.

\section{Pendahuluan}

Menurut Undang-Undang Republik Indonesia Nomor 18 Tahun 2008 tentang Pengelolaan Sampah, pengelolaan sampah rumah tangga dan sampah sejenis sampah rumah tangga adalah perencanaan secara sistematis, menyeluruh, dn berkesinambungan yang meliputi pengurangan dan penanganan sampah. Perencanaan persampahan merupakan langkah awal dalam melaksanakan pembangunan bidang persampahan sebagai dasar pengelolaan baik untuk jangka pendek, menengah maupun jangka panjang. Sedangkan untuk pengurangan sampah dapat dilakukan dengan metode 3R (Reuse, Reduce dan Recycle) di sumber atau di Tempat Pengolahan Sampah 3R (TPST) dan Tempat Pengolahan Sampah Terpadu (TPST). TPS 3R adalah tempat untuk dilaksanakannya kegiatan pengumpulan, pemilahan, penggunaan ulang, dan pendauran ulang skala kawasan (Kementerian Pekerjaan Umum dan Perumahan Rakyat Direktorat Jenderal Cipta Karya, 2017). Penanganan sampah 
sendiri dapat dilakukan dengan pemilahan sampah berdasarkan komponennya, pewadahan, pengumpulan, pengolahan, pemindahan dan pengangkutan sampah, dan pemrosesan akhir sampah. TPST adalah tempat dilaksanakannya kegiatan pengumpulan, pemilahan, penggunaan ulang, pendauran ulang, pengolahan, dan pemrosesan akhir sampah (UU RI No. 18 Tahun 2008).

Meningkatnya laju pembangunan, pertambahan penduduk, serta aktivitas dan tingkat sosial ekonomi masyarakat di Indonesia telah memicu terjadinya peningkatan jumlah timbulan sampah. Semakin besar timbulan sampah yang dihasilkan akan memperbesar dampak negatif dari sampah itu sendiri seperti meningkatnya gangguan kesehatan disebabkan semakin banyak penyakit yang muncul. Selain itu, sampah juga berdampak pada segi estetika dan bila dibiarkan tidak tertutup kemungkinan akan merusak kelestarian lingkungan.

Kabupaten Pasaman Barat adalah salah satu kabupaten di Sumatera Barat, Indonesia dengan luas wilayah $3.887,77 \mathrm{~km}^{2}$ dan jumlah penduduk 410.307 jiwa (BPS Kabupaten Pasaman Barat, 2016) dengan administrasi pemerintahan yang meliputi 11 (sebelas) kecamatan. Penanganan sampah di Kabupaten Pasaman Barat dilakukan oleh Dinas Lingkungan Hidup (DLH) di Bidang Kebersihan dan Pertamanan. Timbulan rata-rata sampah rumah tangga di Kabupaten Pasaman Barat sebesar 2,26 1/o/h sedangkan total timbulan rata-rata sampah pasar sebesar 163,48 1/ unit/h (Dinas Pekerjaan Umum Provinsi Sumatera Barat, 2016).

Kendala yang dihadapi dalam penanganan sampah di Kabupaten Pasaman Barat saat ini yaitu tidak adanya tempat pemilahan dan terbatasnya tempat penampungan dari areal timbulan sampah karena saat ini hanya 9,13\% dari total timbulan sampah Kabupaten Pasaman Barat yang terlayani. Permasalahan lainnya antara lain sarana dan prasarana yang rusak dan sudah melampaui umur pemakaian (lebih dari 5 tahun) sehingga tidak optimal serta praktik minimasi dan pemanfaatan sampah dengan metode $3 \mathrm{R}$ yang tidak terencana.

TPA Muaro Kiawai sebagai tempat pemrosesan akhir sampah di Kabupaten Pasaman Barat juga belum memiliki sertifikat lahan, izin lingkungan, teknologi pengolahan masih dengan cara open dumping, sarana prasarana TPA yang terbatas dan sampah yang masuk ke TPA hanya 4,87\% dari total timbulan sampah Kabupaten Pasaman Barat. Kurangnya partisipasi masyarakat serta aspek pengaturan, kelembagaan dan pembiayaan yang belum berjalan dengan baik juga menjadi kendala dalam pengelolaan sampah di
Kabupaten Pasaman Barat (Dinas Pekerjaan Umum Provinsi Sumatera Barat, 2017)

Sistem pengelolaan sampah yang ideal di Kabupaten Pasaman Barat dapat diwujudkan dengan adanya suatu perencanaan yang diharapkan menjadi acuan dalam pengelolaan sampah di Kabupaten Pasaman Barat. Sesuai dengan Peraturan Menteri Pekerjaan Umum RI Nomor 03/PRT/M/2013, perencanaan umum penyelenggaraan pengelolaan sampah untuk kota sedang dan kecil dalam bentuk perencanaan yang dapat dilakukan selama 15 tahun dengan menggunakan metode $3 \mathrm{R}$, yang memuat aspek teknis operasional yaitu pewadahan, pengumpulan, pengangkutan, pengolahan dan TPA dengan aspek non teknis berupa aspek kelembagaan, pembiayaan, peraturan/ legalitas dan aspek peran serta masyarakat.

Studi mengenai TPS 3R dan TPST dalam kurun 10 tahun terakhir sudah banyak dilakukan baik berupa kajian literatur (Subekti, 2010; Sahwan, 2010) perencanaan (Raharjo dkk, 2016; Rakhmawati dkk, 2016; Azhari, 2017; Primasari, 2010; Cahya dan Pandebesie, 2017), dan perannya dalam mengurangi dampak lingkungan pengelolaan sampah (Raharjo, 2017). Oleh karena itu studi ini penting untuk dilakukan sebagai tahap awal dalam melakukan perencanaan sistem pengelolaan sampah di Kabupaten Pasaman Barat, perlu dianalisis kondisi eksisting pengelolaan sampah yang ada, dan dikaji skenario pengembangan sistem pengelolaan sampah dengan memasukan pendekatan pengolahan sampah ditingkat kawasan yang berbasiskan TPS 3R dan menggunakan TPST sebagai basis reduksi sampah ditingkat skala kota.

\section{Metodologi Penelitian}

Tahapan studi ini terdiri atas:

1. Studi literatur, bertujuan untuk mengumpulkan dan mempelajari teori minimasi dan pemanfaatan sampah berbasis pada TPS3R dan TPST yang bersumber dari buku teks dan jurnal tentang jumlah pengelolaan sampah, serta peraturan-peraturan yang berlaku dan terkait dengan ketentuan umum dan teknis rancangan pengembangan sistem pengelolaan sampah.

2. Pengumpulan data, jenis data yang dikumpulkan berupa data primer, diperoleh dari kuesioner dan wawancara dengan pihak Dinas Lingkungan Hidup Pasaman Barat dan data sekunder yang diperoleh dari telaah dokumen terkait sistem pengelolaan persampahan Kabupaten Pasaman Barat.

3. Identifikasi permasalahan dan kebutuhan pengembangan aspek teknis dan non teknis 
pengelolaan sampah Kabupaten Pasaman Barat dengan membandingkan kondisi eksisting dengan standar pengelolaan sampah kota menurut Standar Nasional Indonesia Nomor SNI 19-2454-2002 tentang Tata Cara Teknis Operasional Pengelolaan Sampah Perkotaan dan Peraturan Menteri Pekerjaan Umum RI Nomor 03/PRT/M/2013.

4. Kajian Skenario Pengembangan Sistem Pengelolaan Sampah dilakukan terhadap system pengelolaan sampah saat ini dan potensi pengembangannya dengan pendekatan pengolahan skala kawasan dan skala kota, kelebihan dan keunggulan pengembangan sistem yang diusulkan dengan parameter tingkat reduksi sampah.

\section{Hasil dan Pembahasan}

\subsection{Identifikasi Permasalahan dan Kebutuhan Pengembangan}

Permasalahan pengelolaan sampah saat ini di Kabupaten Pasaman Barat meliputi:

1. Tingkat pelayanan sampah tahun 2016 adalah sebesar 9,13\% dan daerah pelayanan hanya sebesar 10,30\%, target RPJMN 2015 yang seharusnya yatu $100 \%$.

2. Aspek teknis yang terdiri atas:

\section{a. Pewadahan}

Sistem pewadahan individual Kabupaten Pasaman Barat berasal dari pihak masyarakat itu sendiri hal ini dapat dilihat dari hasil kuesioner, dengan wadah berupa karung, keranjang, plastik dan ember. Sistem pewadahan Komunal yang ada di Kabupaten Pasaman Barat ini masih memakai pewadahan sistem tercampur berupa kontainer. Jumlah wadah yang sudah disediakan oleh pemerintah Kabupaten Pasaman Barat tidak mencukupi dengan jumlah sampah yang dihasilkan, dengan daya tampung pewadahan yang sudah ada sebesar $96 \mathrm{~m}^{3} / \mathrm{h}$ sementara total volume sampah yang dihasilkan Kabupaten Pasaman Barat sebesar $1076,60 \mathrm{~m}^{3} / \mathrm{h}$.

\section{b. Pengumpulan}

Pola pengumpulan yang di Kabupaten Pasaman Barat ini yaitu pola individual tidak langsung, komunal langsung dan pola penyapuan jalan. Dengan sistem pengumpulan sampah tanpa pemilahan sama sekali. Prasarana dan sarana yang digunakan dalam pengumpulan berupa becak motor dengan 7 unit kondisi baik kapasitas $1,5 \mathrm{~m}^{3}$ dimana baru 6 unit yang beroperasi dan itu hanya di Kota
Simpang Empat Kecamatan Pasaman untuk mengumpulkan sampah dari perumahanperumahan menuju kontainer terdekat sedangkan 1 unit digunakan untuk mengangkut residu sampah Bank Sampah Kinali menuju TPA. Pengumpulan dengan becak sampah kapasitas $1 \mathrm{~m}^{3}$ hanya untuk penyapuan jalan sebelum dibawa ke kontainer terdekat. Jumlah becak motor dan becak sampah belum mencukupi untuk mengumpulkan jumlah sampah total yang dihasilkan di Kabupaten Pasaman Barat.

\section{c. Pengangkutan}

Sistem pengangkutan di Kabupaten Pasaman Barat dilakukan dengan pola Stationary Container System (SCS) dan sistem transfer dengan pola Hauled Container System (HCS). Sistem HCS digunakan untuk mengangkut sampah dari kontainer sedangkan sistem SCS digunakan untuk pengumpulan sampah di luar kontainer termasuk sampah yang diletakkan masyarakat di pinggir-pinggir jalan oleh masyarakat. Sistem pengangkutan Kabupaten Pasaman Barat ini terkendala di sarana prasarana, dimana jumlah truk yang ada untuk mengangkut jumlah total sampah belum mencukupi dan pengambilan sampah dari kontainer terkadang tidak sesuai dengan rute pengangkutan yang sudah ada sehingga banyak sampah yang tidak terangkut ke TPA.

\section{d. Sistem Pengolahan Sampah}

Permasalahan pengolahan sampah yang ada di Kabupaten Pasaman Barat ini adalah sebagai berikut:

1) Berdasarkan data yang diperoleh Bank sampah Kinali yang menerapkan sistem pengelolaan $3 \mathrm{R}$ yang berbasis masyarakat berupa kegiatan kerajinan daur ulang hanya 1,22\% dari total sampah Kecamatan Kinali yang masuk ke bank sampah untuk diolah;

2) Belum dioperasikannya Tempat Pengolahan Sampah Terpadu (TPST) Sungai Beremas karena baru selesai dibangun pada tahun 2016;

3) Tidak adanya usaha pengurangan sampah oleh masyarakat berdasarkan hasil survei lapangan;

4) Masyarakat Kabupaten Pasaman Barat yang masih melakukan pembakaran, penimbunan dan pembuangan sampah ke tanah/ sungai karena belum adanya kepedulian masyarakat untuk memanfaatkan sampah yang masih bisa digunakan.

e. Tempat Pemrosesan Akhir (TPA)

Permasalahan TPA untuk Kabupaten Pasaman 
Barat ini adalah sebagai berikut:

1) Lokasi TPA tersedia saat ini di Muaro Kiawai belum memiliki sertifikat lahan yang sah;

2) Kurangnya sarana prasarana TPA untuk menunjang pengelolaan lingkungan sekitar TPA;

3) Belum tersedianya master plan dan dokumen perencanaan TPA namun studi kelayakan dan DED sudah ada;

4) Belum adanya izin lingkungan (AMDAL dan $\mathrm{UKL} / \mathrm{UPL}$ );

5) Masih menggunakan sistem open dumping.

Berdasarkan permasalahan yang teridentifikasi diatas, maka pengembangan yang harus dilakukan adalah:

1. Tingkat dan Daerah Pelayanan

Adapun kebutuhan pengembangan yang perlu dilakukan adalah sebagai berikut:

a. Perlunya zonasi daerah pelayanan agar dapat mempermudah monitoring dan peningkatan daerah pelayanan;

b. Perlunya pembagian skala pengelolaan sampah menjadi skala kawasan dan skala kota;

c. Perlunya peningkatan tingkat pelayanan hingga mencapai standar pelayanan minimal pada jangka pendek dan terus terjadi peningkatan pada akhir periode desain terutama pada zona prioritas pelayanan.

\section{Aspek teknis operasional}

a. Pewadahan

Kebutuhan pengembangan untuk periode desain pewadahan adalah sebagai berikut:

1) Jenis pewadahan yang direncanakan adalah pewadahan terpilah untuk sampah mudah terurai, sampah daur ulang dan sampah lainlain;

2) Perlu adanya sosialisasi tentang pemilahan sampah di sumber pada wilayah Kabupaten Pasaman Barat khususnya yang menjadi prioritas zona pengembangan $3 \mathrm{R}$ berbasis masyarakat sehingga dapat diterapkan pewadahan terpisah yang dimulai dari sumber;

3) Penambahan pewadahan komunal pada skala kawasan untuk sumber sampah domestik sebelum diangkut menuju TPS 3R dan pewadahan komunal skala kota untuk menampung sampah-sampah yang belum terlayani oleh TPS 3R;

4) Penggantian wadah yang sudah melewati umur teknis.

b. Pengumpulan
Adapun kebutuhan pengembangan dalam sistem pengumpulan yang dapat direncanakan adalah sebagai berikut:

1) Pola individual tidak langsung dikembangkan untuk kawasan yang akan dibangun TPS 3R;

2) Pola komunal tidak langsung ditambahkan pada skala kawasan untuk sumber sampah domestik yang akan dikumpulkan di TPS 3R;

3) Pola penyapuan jalan untuk sampah jalan-jalan protokol dan pusat kota;

4) Pola komunal langsung dikembangkan untuk kawasan yang belum memiliki TPS 3R (skala kota);

5) Melakukan pembangunan sarana pengumpulan berupa TPS $3 R$ pada skala kawasan dengan penambahan jumlah becak motor;

6) Mengoptimalkan bangunan TPST yang sudah ada;

7) Melakukan pembangunan sarana pengumpulan berupa TPST pada skala kota dengan penambahan jumlah armroll truck dan becak sampah;

8) Penggantian sarana pengumpulan yang telah melewati umur teknis.

\section{c. Pengangkutan}

Kebutuhan pengembangan dari sistem pengangkutan sampah pada periode perencanaan adalah sebagai berikut:

1) Memaksimalkan jumlah ritasi alat angkut;

2) Merencanakan rute pengangkutan terpendek;

3) Menggunakan dump truck sampai umur teknisnya habis dan menggunakan armroll truck hingga akhir perencanaan;

4) Penambahan sarana pengangkutan berupa armroll truck;

5) Pengaturan jadwal pengangkutan kontainer (pewadahan komunal) dan residu sampah.

d. Pengolahan

Pengolahan Kebutuhan pengembangan yang dapat dilakukan adalah sebagai berikut:

1) Membangun bangunan pengolahan sampah berupa TPS 3R;

2) Mengoptimalkan kinerja bank sampah yang masih berjalan dan memulai pengoperasian TPST yang sudah dibangun;

3) Membangun bangunan pengolahan sampah berupa TPST di kawasan TPA untuk meminimalisir jumlah sampah yang akan diurug dengan melakukan pengolahan pada sampah tercampur skala kota;

4) Berdasarkan kuesioner $100 \%$ responden menyambut baik jika bangunan pengolahan 
sampah dibangun di daerahnya namun $85 \%$ keberatan jika harus membayar retribusi persampahan sehingga perlu dilakukan sosialisasi dan pelatihan lebih lanjut terkait penambahan TPS 3R untuk meningkatkan peran serta masyarakat dalam pengolahan sampah.

\section{e. Pemrosesan akhir}

Kebutuhan pengembangan yang dapat dilakukan untuk TPA adalah sebagai berikut:

1. Berdasarkan hasil wawancara dengan DLH Kabupaten Pasaman Barat untuk pemrosesan akhir sampah akan tetap dilakukan di TPA Muaro Kiawai dengan mengurus sertifikat lahan dan izin lingkungan untuk mengontrak TPA hingga penuh;

2. Merencanakan sistem penimbunan sampah sanitary landfill;

3. Menambah sarana prasarana TPA sehingga menjadi lebih layak;

4. Menghitung kebutuhan luas lahan TPA hingga akhir periode desain sehingga dibutuhkan/ tidaknya lahan TPA baru dapat diketahui.

\subsection{Skenario Pengembangan}

\subsubsection{Sistem Pengelolaan Sampah Eksisting}

Sistem pengelolaan sampah yang ada sekarang dapat dilihat pada Gambar 1, belum ada kegiatan minimisasi sampah yang berarti, sampah yang berasal dari sumber sampah yang dilayani dikumpulkan dan diangkut ke TPA untuk diurug.

\subsubsection{Skala Pengelolaan Kawasan dan Kota}

Skala pengelolaan yang diusulkan untuk dikembangan untuk sistem pengelolaan sampah Kabupaten Pasaman Barat ke depan dibagi menjadi 2 (dua) kelompok, yaitu skala kawasan dan skala kota. Hal ini bertujuan untuk meminimasi volume sampah yang masuk ke TPA. Prioritas utama dalam perencanaan ini yaitu pengelolaan sampah skala kawasan kemudian baru skala kota dengan alasan

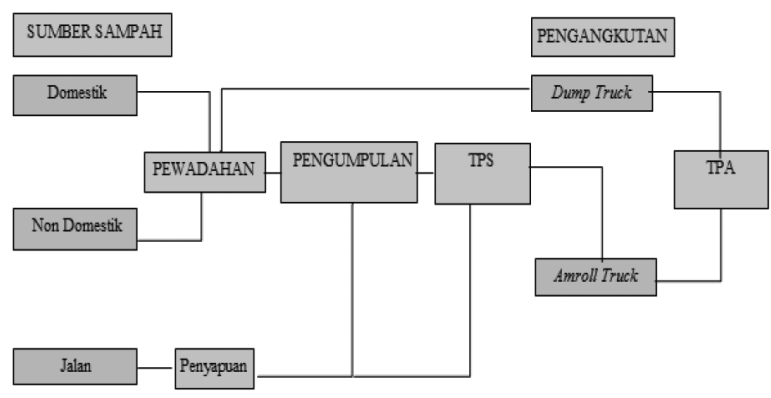

Gambar 1. Skema pengelolaan sampah eksisting Kabupaten Pasaman Barat sesuai paradigma baru pengelolaan sampah yang berwawasan lingkungan dan berbasis masyarakat. Strategi yang digunakan dalam tingkat pengelolaan sampah adalah meningkatkan tingkat pengelolaan kawasan dan mengurangi tingkat pengelolaan sampah skala kota.

Secara lebih jelas pengembangan sistem pengelolaan skala kawasan dapat dilihat pada Gambar 2.

Sampah dari sumber domestik sudah dipilah menjadi sampah mudah terurai, sampah daur ulang, dan sampah lain-lain. Sampah dikumpulkan dan diolah di TPS 3R, sampah yang mudah terurai akan dikompos, sampah yang dapat didaur ulang akan dibersihkan dan dikemas untuk dijual, dan sampah selain itu akan diletakkan pada kontainer sampah residu, dan kemudian akan dijemput oleh truk sampah dan dibawa ke TPA.

Sedangkan untuk sistem pengelolaan sampah skala kota yang diusulkan dapat dilihat pada Gambar 3, sampah dari selain sumber domestik akan dikumpulkan secara tercampur dan dikumpulkan dan ditempatkan di kontainer, truk sampah akan menjemput dan akan membawanya ke TPST untuk diolah dengan pemilahan terlebih dahulu, dikompos bagi yang layak kompos, didaur ulang untuk yang layak daur ulang, dan sisanya diurug di TPA.

\subsubsection{Tingkat Reduksi Sampah dan Kebutuhan Prasarana dan Sarana Pengelolaan Sampah}

Tingkat reduksi sampah melalui target $3 \mathrm{R}$ yang direncanakan pada studi pengembangan pengelolaan sampah Kabupaten Pasaman Barat ini sebesar 30\% hingga akhir periode perencanaan dengan realisasi target sebesar $22,40 \%$.

Adapun kebutuhan prasarana dan sarana sistem pengelolaan sampah yang dikembangkan selama 15 tahun kedepan adalah seperti terlihat pada Tabel 1.

\section{Kesimpulan}

Berdasarkan analisis kondisi eksisting sistem pengelolaan sampah yang ada dan kajian alternatif sistem pengelolaan sampah yang dikembangkan maka berikut merupakan beberapa kesimpulan dan saran bagi pihak terkait:

1. Permasalahan pengelolaan sampah yang dihadapi Kabupaten Pasaman Barat saat ini adalah tingkat dan daerah pelayanan yang masih rendah, yaitu $9,13 \%$ dan $10,30 \%$, sarana dan prasarana teknis operasional sampah yang kurang memadai, belum meratanya penanganan sampah pada cakupan daerah layanan dan rendahnya praktik minimasi dan pemanfaatan sampah, operasional TPA yang masih belum 


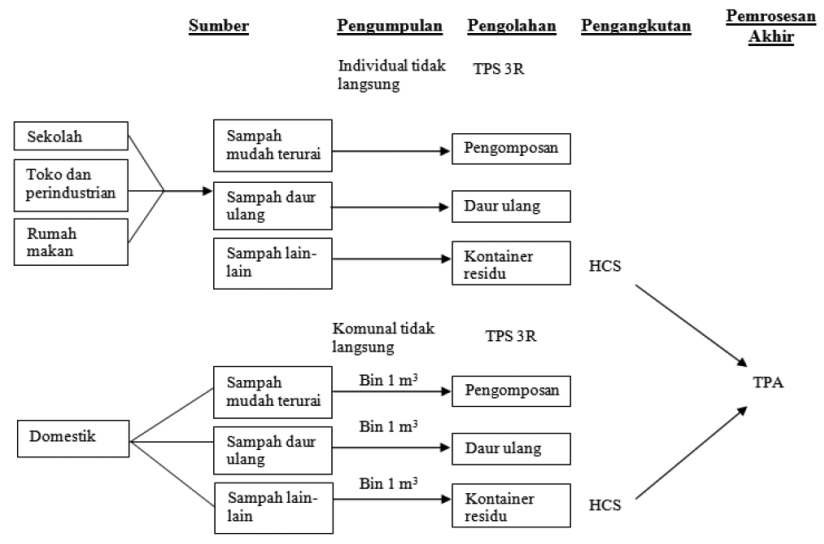

Gambar 2. Skema pengelolaan sampah skala kawasan memenuhi standar.

2. Alternatif sistem pengelolaan sampah yang dapat diterapkan untuk menanggulangi permasalahan sampah di Kabupaten Pasaman Barat adalah dengan menerapan sistem pengelolaan sampah skala kawasan untuk sumber domestik dan skala kota untuk sumber lainnya, dengan berbasiskan kepada TPS3R untuk skala kawasan dan TPST untuk skala kota.

3. Dengan penerapan sistem pengelolaan sampah skala kawasan dan kota ini selama 15 tahun kedepan akan dapat mereduksi sampah ke TPA sebesar $22,40 \%$, dengan kebutuhan prasarana dan sarananya berupa: pewadahan komunal 1 $\mathrm{m}^{3}$ sebanyak 750 buah, pewadahan komunal $8 \mathrm{~m}^{3}$ sebanyak 148 buah, becak motor 1,5 $\mathrm{m}^{3}$ sebanyak 91 buah, becak sampah $1 \mathrm{~m}^{3}$ sebanyak 11 buah, arm roll truk sebanyak 65 buah, TPS 3R tipe I sebanyak 3 buah, TPS3R tipe II sebanyak 17 buah, TPST sebanyak 2 buah, dan TPA dengan luas 6,34 Ha.

Adapun saran terkait dengan hasil studi ini adalah:

1. Perlu dikaji juga aspek non teknis sistem pengelolaan sampah yang diusulkan meliputi pengelola, peraturan, pembiayaan dan aspek peran serta masyarakat.

2. Pemerintah dapat menjadikan hasil kajian ini sebagai dasar dalam mengembangkan sistem

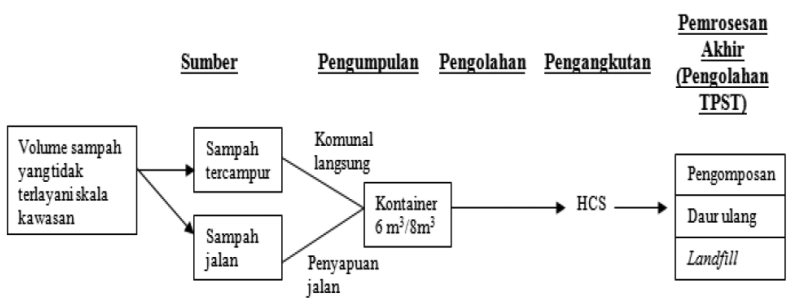

Gambar 3. Skema pengelolaan sampah skala kota
Tabel 1. Kebutuhan prasarana dan sarana pengembangan sistem pengelolaan sampah Kabupaten Pasaman Barat

\begin{tabular}{|c|c|c|c|c|}
\hline Subsistem & $\begin{array}{c}\text { Prasarana } \\
\text { Sarana }\end{array}$ & Volume & Jumlah & Unit \\
\hline \multirow[t]{2}{*}{ Pewadahan } & $\begin{array}{c}\text { Wadah } \\
\text { komunal }\end{array}$ & $1 \mathrm{~m}^{3}$ & 750 & buah \\
\hline & & $8 \mathrm{~m}^{3}$ & 148 & buah \\
\hline \multirow[t]{2}{*}{ Pengumpulan } & $\begin{array}{l}\text { Becak } \\
\text { motor }\end{array}$ & $1,5 \mathrm{~m}^{3}$ & 91 & buah \\
\hline & $\begin{array}{c}\text { Becak } \\
\text { sampah }\end{array}$ & $1 \mathrm{~m}^{3}$ & 11 & buah \\
\hline Pengangkutan & $\begin{array}{c}\text { Arm roll } \\
\text { truk }\end{array}$ & $8 \mathrm{~m}^{3}$ & 65 & buah \\
\hline \multirow[t]{3}{*}{ Pengolahan } & $\begin{array}{l}\text { TPS3R } \\
\text { type } 1\end{array}$ & $500 \mathrm{~m}^{2}$ & 3 & buah \\
\hline & $\begin{array}{l}\text { TPS3R } \\
\text { type } 2\end{array}$ & $900 \mathrm{~m}^{2}$ & 17 & buah \\
\hline & TPST & $2 \mathrm{Ha}$ & 2 & buah \\
\hline $\begin{array}{c}\text { Pemrosesan } \\
\text { Akhir }\end{array}$ & TPA & $6,34 \mathrm{Ha}$ & 1 & buah \\
\hline
\end{tabular}

pengelolaan sampah kota yang lebih baik kedepannya yaitu dengan meningkatkan upaya minimasi sampah di tingkat kawasan dan juga kota sehingga kebutuhan akan TPA semakin dapat dikurangi.

\section{Daftar Pustaka}

Azhari, Deni Rezki. (2017) Perencanaan Tempat Pengolahan Sampah Terpadu 3R di Kelurahan Pemurus Dalam Kota Banjarmasin. Tugas Akhir. Universitas Muhammadiyah Malang.

Badan Pusat Statistik Kabupaten Pasaman Barat. (2016). Kabupaten Pasaman Barat dalam Angka

Badan Standarisasi Nasional. (2002). Standar Nasional Indonesia Nomor SNI 19-2454-2002 tentang Tata Cara Teknis Operasional Pengelolaan Sampah Perkotaan

Cahya, Widya Indira dan Pandebesie, Ellina Sitepu. (2017). Kajian Tempat Pengolahan Sampah Terpadu Gunung Bahagia, Kota Balikpapan. Jurnal Teknis ITS. Vol.6 (2):170-174

Dinas Lingkungan Hidup Kabupaten Pasaman Barat. (2017). Kondisi Pengelolaan Persampahan Kabupaten Pasaman Barat

Dinas Pekerjaan Umum Provinsi Sumatera Barat. (2016). Perencanaan Teknis dan Manajemen Persampahan Kabupaten Pasaman Barat Tahun 2016

Kementerian Pekerjaan Umum. (2013). Peraturan Menteri Pekerjaan Umum Nomor 3/PRT/M/2013 tentang Penyelenggaraan Prasarana dan Sarana Persampahan dalam Penanganan Sampah Rumah Tangga dan Sampah Sejenis Sampah Rumah Tangga

Kementerian Pekerjaan Umum dan Perumahan 
Rakyat Direktorat Jenderal Cipta Karya. (2017). Petunjuk Teknis Tempat Pengolahan Sampah (TPS) 3R

Primasari, Indri. (2010). Perencanaan Pengelolaan Sampah Terpadu Berbasis 3R di Kecamatan Ngaliyan. Tugas Akhir. Universitas Diponegoro. Raharjo, Slamet. (2017). Development of 3R Waste Treatment Facilities for Mitigating Greenhouse Gas emission: A Case Study of Padang City, Indonesia. ARPN Journal of Engineering and Applied Sciences. Vol. 12 (12): 3789-3794

Raharjo, Slamet; Ihsan, Taufiq; dan yuned, Sri Rahmiwati. (2016). Pengembangan Pengelolaan Sampah Perkotaan dengan Pemanfaatan Sampah Berbasis Masyarakat. Jurnal Dampak. Vol.13 (1): $10-25$
Rakhmawati, Arna Puji; Soemitro Ria A.A.; dan Warmadewanthi, I.D.A.A. (2016). Waste management Analysis At TPS 3R Mandiri Sejahtera Singosari Malang. The 2nd International Conference on Civil Engineering Research (ICCER) 2016. p 65-70

Sahwan, Firman L. (2010). Tempat Pengolahan Sampah Terpadu (TPST), Urgensi dan Implementasinya. JRL. Vol.6 (2): 151-157

Subekti, Sri. (2010). Pengelolaan Sampah Rumah Tangga 3R Berbasis Masyarakat. Prosiding Seminar Nasional Sains dan Teknologi 2010. p 24-30

Undang-Undang Republik Indonesia Nomor 18 Tahun 2008 tentang Pengelolaan Sampah 